\title{
PROMETNO GEOGRAFSKI VIDIKI NOVE DRŽAVNE MEJE
}

\author{
Andrej Černe*, Stanko Pelc**
}

Izvleček

UDK 911.3:656(497.12)

Prikazane so osnovne prometno geografske značilnosti meja Slovenije in najnovejše spremembe v obsegu, prostorski usmeritvi in strukturi prometnih tokov med leti 1985-1992 na magistralnih in regionalnih cestah ter izbranih mejnih prehodih na slovensko-hrvaški meji.

Ključne besede: Geografija prometa, prometni tokovi, slovensko hrvaška meja, mejni prehodi

The article presents basic transport geographic characteristics of Slovene borders and contemporary changes of transport flows between 1985 and 1992 at the road network and selected border crossings at Slovene-Croat border.

Kay words: Transport geography, traffic flows, Slovene-Croat border, border crossings

\section{NEKATERE PROMETNO GEOGRAFSKE ZNAČILNOSTI OBČIN OB SLOVENSKO-HRVAŠKI MEJI}

Ob slovensko-hrvaški meji leži 17 občin, ki se po stopnji motorizacije zelo razlikujejo. Občina Metlika je imela leta 19913.208 osebnih vozil, občina Ptuj pa 23.709. V 17. občinah je bilo 178.201 osebnih vozil, kar je predstavljalo slabo četrtino $(23,6 \%)$ vseh osebnih vozil v Sloveniji. Zato je bila tudi obremenitev magistralnega in regionalnega prometnega omrežja zelo raznolika, od 42 osebnih avtomobilov na $\mathrm{km}$ magistralnih in regionalnih cest v občini Metlika do 292 v občini Piran. Samo občina Piran in Koper sta imeli večjo gostoto od slovenskega povprečja, ki je znašala 124 osebnih vozil na km magistralnih in regionalnih cest.

Železniški potniški in blagovni promet potekata v vseh občinah, razen v občini Piran, ki nima železniškega omrežja, $v$ občinah Kočevje in Ribnica pa poteka samo blagovni promet. Leta 1991 je bilo na 69. železniških postajah (32,0\% vseh postaj v Sloveniji) v 16. občinah ob slovensko-hrvaški meji odpravljeno 2,04 milijone potnikov, kar je predstavljalo 15,3\% vseh potnikov v Sloveniji. Železnica je imela največji pomen v potniškem prometu občin: Novo mesto, Črnomelj, Ormož in Ptuj, kjer je bilo odpravljenih več kot $55 \%$ vseh potnikov

* Dr., doc., Oddelek za geografijo, Filozofska fakulteta, Univerza v Ljubljani, 610000 Ljubljana, Aškerčeva 2, SLO.

** Dr., samostojni raziskovalec, Prevoje 19, 61225 Lukovica, SLO. 
v obmejnih občinah. Kljub temu pa je bilo samo v občinah Črnomelj in Novo mesto odpravljenih več potnikov na železnici od občinskega povprečja (272.000) v Sloveniji.

Tab. 1: Stopnja motorizacije in gostota magistralnih in regionalnih cest $\mathrm{v}$ občinah ob slovensko-hrvaški meji leta 1991*

The degree of Motorization and the Density of Magistral and Regional Road Network in the Frontier Communities at the Slovene-Croat Border 1991

\begin{tabular}{l|r|r|r}
\hline $\begin{array}{l}\text { Občine } \\
\text { Communes }\end{array}$ & $\begin{array}{r}\text { Osebna vozila } \\
\text { Private cars }\end{array}$ & $\begin{array}{r}\text { Prebivalci/osebno } \\
\text { vozilo } \\
\text { Inhabitants/private } \\
\text { car }\end{array}$ & $\begin{array}{r}\text { Gostota mag.+reg. } \\
\text { cest km/km2 } \\
\text { Density mag.+reg. } \\
\text { roads km/km2 }\end{array}$ \\
\hline Brežice & & 3 & 0,28 \\
Cerknica & 6684 & 3 & 0,14 \\
Črnomelj & 4657 & 4 & 0,12 \\
Ilirska Bistrica & 4489 & 3 & 0,22 \\
Kočevje & 4738 & 3 & 0,15 \\
Koper & 5079 & 2 & 0,32 \\
Krško & 18937 & 3 & 0,23 \\
Lendava & 7753 & 4 & 0,29 \\
Ljutomer & 5824 & 4 & 0,27 \\
Metlika & 4549 & 4 & 0,38 \\
Novo mesto & 2084 & 3 & 0,21 \\
Ormož & 17330 & 5 & 0,20 \\
Piran & 3451 & 2 & 0,48 \\
Ptuj & 6443 & 4 & 0,25 \\
Ribnica & 16348 & 3 & 0,16 \\
Šžana & 3392 & 2 & 0,24 \\
Śmarje pri Jelšah & 9730 & 4 & 0,27 \\
SLOVENIJA & 7188 & 3 & 0,23 \\
\hline
\end{tabular}

* Statistični podatki po obð̌inah, Zavod R Slovenije za statistiko, Ljubljana, 1992

V železniškem blagovnem prometu je bilo na območju obmejnih občin naloženih in razloženih 6,3 milijone ton blaga ali kar $43,2 \%$ vsega blaga v Sloveniji. Pri tem gre za izrazito vlogo Kopra, kjer so naložili in razložili kar $56,2 \%$ vsega blaga na železnici v obmejnih občinah. $\mathrm{V}$ občini Koper so tega leta na sploh naložili in razložili največ blaga $\mathrm{v}$ Sloveniji. Občine Koper, Ptuj, Krško, Ormož in Novo mesto so imele nadpovprečni blagovni promet na železnici, saj je bilo $\mathrm{v}$ teh občinah naloženega in razloženega več blaga kot je bilo občinsko povprečje (275.000t) v Sloveniji. V občinah Ribnica, Metlika, Cerknica, 
Prometno geografski vidiki...

Tab. 2: Promet potnikov in blaga v železniškem prometu v občinah ob slovensko-hrvaški meji leta $1991^{*}$

Passenger and good Railway Traffic in the Frontier Communes at the SloveneCroat Border 1991

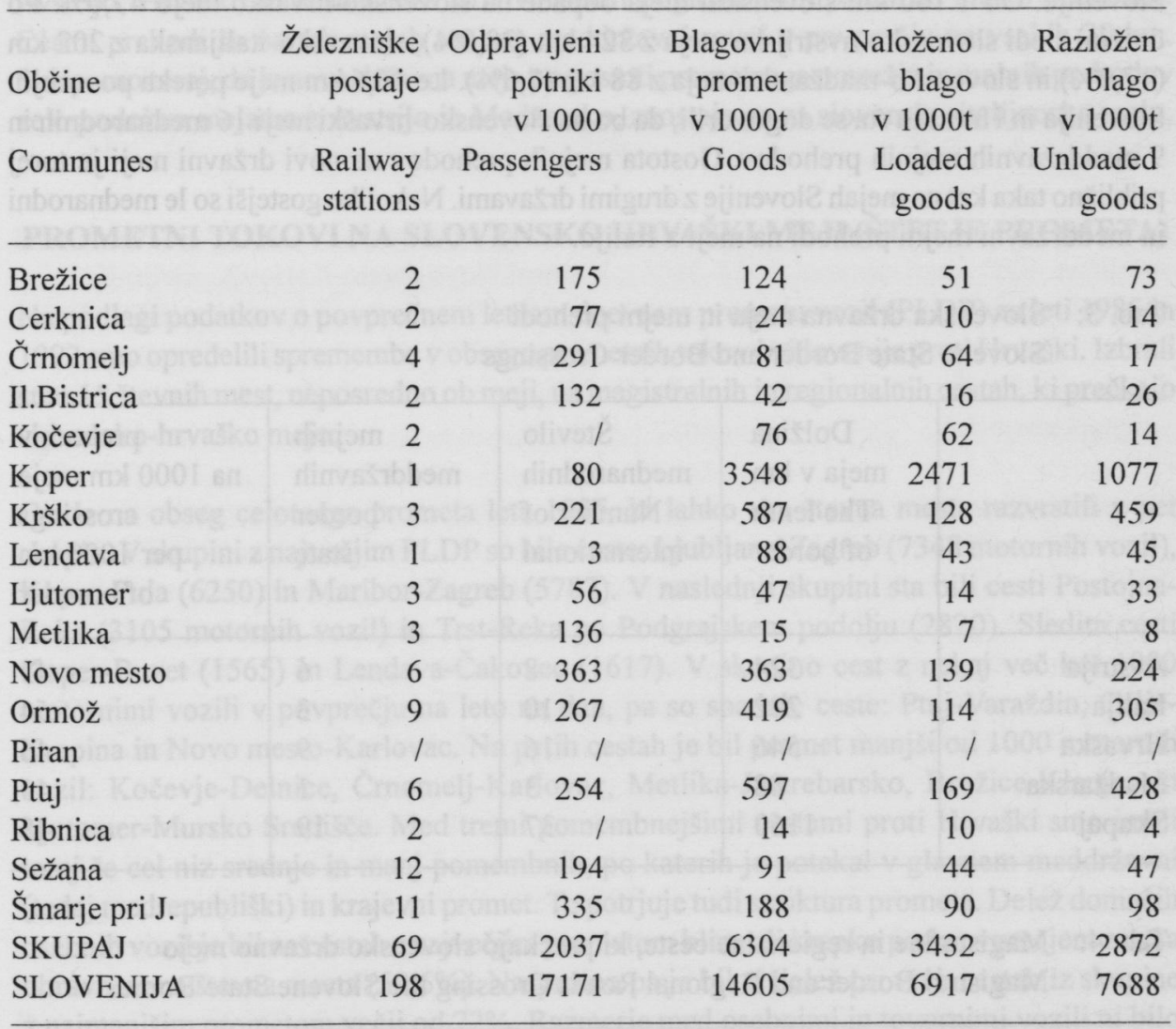

*Statistični podatki po občinah, Zavod R Slovenije za statistiko, Ljubljana, 1992

Ilirska Bistrica in Ljutomer delež naloženega in razloženega blaga ne presega $1 \%$ železniškega blagovnega prometa na slovensko-hrvaški meji. Železnica je imela v obmejnih občinah večji pomen za odvoz kot pa za dovoz blaga. Na železnici so namreč v teh občinah naložili 3,4 tone blaga, ali skoraj polovico vsega naloženega blaga v Sloveniji (49,6\%), razložili pa 2,8 milijonov ton, ali 37,3\% vsega razloženega blaga v Sloveniji. 


\section{NOVA MEJA IN MEJNI PREHODI}

$\mathrm{Z}$ osamosvojitvijo se je južna in jugovzhodna meja Slovenije spremenila iz notranje medrepubliške v mejo med dvema samostojnima državama in je s $546 \mathrm{~km}$ najdaljša meja Slovenije. Od $1.160 \mathrm{~km}$ slovenskih meja odpade na slovensko-hrvaško mejo 47,0\%. Po dolžini sledi slovensko-avstrijska meja z $324 \mathrm{~km}(28,0 \%)$, slovensko-italijanska z $202 \mathrm{~km}$ $(17,0 \%)$ in slovensko-madžarska meja z $88 \mathrm{~km}(7,6 \%)$. Le 46,6 km meje poteka po morju. Slovenija in Hrvaška sta se dogovorili, da bo na slovensko-hrvaški meji 16 mednarodnih in 9 meddržavnih mejnih prehodov. Gostota mejnih prehodov na novi državni meji je torej približno taka kot na mejah Slovenije z drugimi državami. Nekoliko gostejši so le mednarodni in meddržavni mejni prehodi na meji z Italijo.

Tab. 3: Slovenska državna meja in mejni prehodi Slovene State Border and Border Crossings

\begin{tabular}{l|r|r|r|r}
\hline & $\begin{array}{r}\text { Dolžina } \\
\text { meja v km } \\
\text { The lenth } \\
\text { of border }\end{array}$ & $\begin{array}{r}\text { Število } \\
\text { mednarodnih } \\
\text { Number of } \\
\text { international }\end{array}$ & $\begin{array}{r}\text { mejnih } \\
\text { meddržavnih } \\
\text { border } \\
\text { state }\end{array}$ & $\begin{array}{r}\text { prehodov } \\
\text { na } 1000 \mathrm{~km} \text { meje } \\
\text { crossings } \\
\text { per } 1000 \mathrm{~km} \\
\text { of boreder }\end{array}$ \\
\hline Avstrija & 324 & 8 & 6 & 43 \\
Italija & 202 & 10 & 3 & 64 \\
Hrvaška & 546 & 16 & 9 & 46 \\
Madžarska & 88 & 3 & 1 & 45 \\
Skupaj & 1160 & 37 & 19 & 48 \\
\hline
\end{tabular}

Tab. 4: Magistralne in regionalne ceste, ki prečkajo slovensko državno mejo Magistral Border and Regional Roads Crossing the Slovene State Border

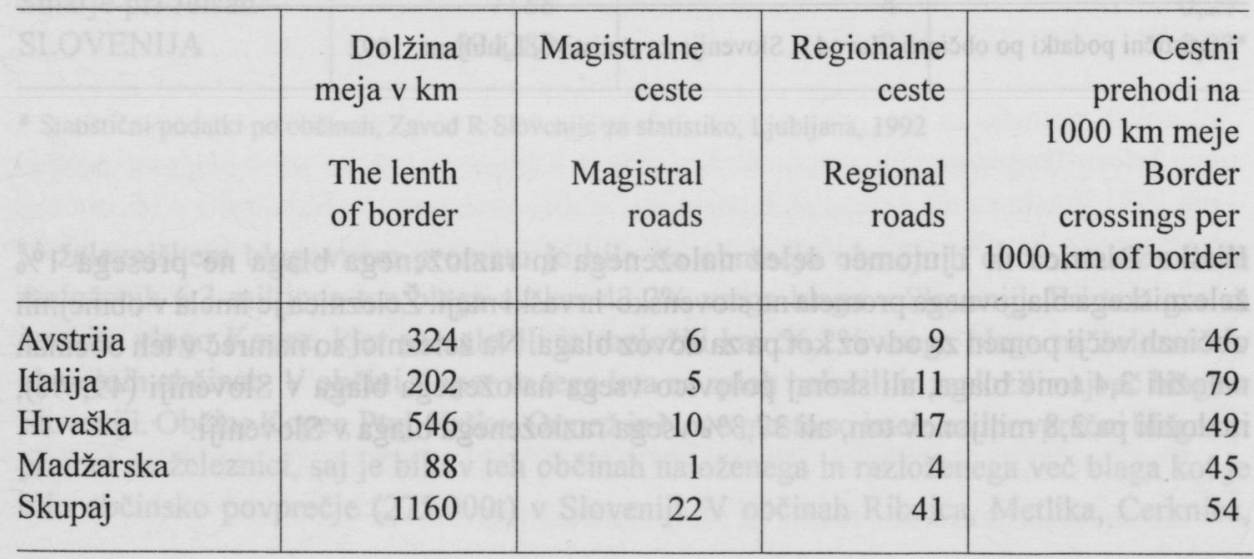


Iz obeh preglednic je razvidno, da je gostota magistralnih in regionalnih cest, ki prečkajo slovensko-italijansko mejo, nekoliko večja od gostote madnarodnih in meddržavnih mejnih prehodov. Na drugih mejah je gostota magistralnih in regionalnih cest, ki vodijo preko meja skoraj povsem enaka gostoti mednarodnih in meddržavnih mejnih prehodov. Meje z Avstrijo, Hrvaško in Madžarsko so $v$ fizičnem pogledu torej približno enako prehodne. Cestni prehodi so na teh mejah vsaj na meddržavni ravni v povprečju na vsakih $20 \mathrm{~km}$. Sklepamo torej, da je nova državna meja po gostoti prometnega omrežja in mejnih prehodov zelo podobna mejama z Avstrijo in Madžarsko, zaostaja pa za slovensko-italijansko mejo.

\section{PROMETNI TOKOVI NA SLOVENSKO HRVAŠKI MEJI (ŠTETJE PROMETA)}

Na podlagi podatkov o povprečnem letnem dnevnem prometu vozil (PLDP) za leti 1985 in 1992 smo opredelili spremembe v obsegu prometnih tokov iz Slovenije proti Hrvaški. Izbrali smo 15 števnih mest, neposredno ob meji, na magistralnih in regionalnih cestah, ki prečkajo slovensko-hrvaško mejo.

Glede na obseg celotnega prometa leta 1985 , bi lahko vsa števna mesta razvrstili v pet skupin. V skupini z največjim PLDP so bile ceste: Ljubljana-Zagreb (7348 motornih vozil), Koper-Pula (6250) in Maribor-Zagreb (5787). V naslednji skupini sta bili cesti PostojnaReka (3105 motornih vozil) in Trst-Reka po Podgrajskem podolju (2820). Sledita cesti Koper-Buzet (1565) in Lendava-Čakovec (1617). V skupino cest z nekaj več kot 1000 motornimi vozili v povprečju na leto na dan, pa so spadale ceste: Ptuj-Varaždin, CeljeKrapina in Novo mesto-Karlovac. Na petih cestah je bil promet manjši od 1000 motornih vozil: Kočevje-Delnice, Črnomelj-Karlovac, Metlika-Jastrebarsko, Brežice-Klanjec in Ljutomer-Mursko Središče. Med tremi pomembnejšimi cestami proti Hrvaški smo imeli torej še cel niz srednje in manj pomembnih, po katerih je potekal $v$ glavnem meddržavni (tedaj medrepubliški) in krajevni promet. To potrjuje tudi struktura prometa. Delež domačih osebnih vozil je bil na cestah z največjim prometom blizu ali krepko pod povprečjem za vsa obravnavana števna mesta $(50,6 \%)$. Nasprotno pa je bil ta delež pri vseh cestah iz skupine $\mathrm{z}$ najmanjšim prometom večji od $72 \%$. Razmerje med osebnimi in tovornimi vozili ni bilo povezano z obsegom skupnega prometa. Največji je bil delež tovornega prometa na cestah Celje-Krapina in Ljutomer-Mursko Središče. Zelo majhen je bil ta delež na eni najbolj prometnih cest Koper-Pula (13,3\%), predvsem zaradi velikega deleža turističnega prometa. Najmanjši delež tovornih vozil je prečkal slovensko-hrvaško mejo v Ormožu $(12,1 \%)$, kar je verjetno posledica omejitve za tovorni promet na tamkajšnjem mostu.

Z nastankom nove državne meje, predvsem pa s spremenjenimi geopolitičnimi in gospodarskimi razmerami na območju nekdanje Jugoslavije pa tudi celotne vzhodne Evrope, je prišlo tudi do spremembe prometnih tokov v smeri iz Slovenije proti Hrvaški. Promet (PLDP) se je zmanjšal predvsem na dveh najbolj obremenjenih cestah Ljubljana-Zagreb in Maribor-Zagreb, saj sta obe evropski magistralni smeri zaradi vojne prekinjeni in lahko služita le še povezovanju dela Hrvaške z Evropo. Po cestah Ljubljana-Zagreb in Ljubljana- 
Reka je potekal tudi del prometa med Istro in Zagrebom, saj je bila cesta Reka-Karlovac zaradi bližine kriznih (vojnih) območij mnogokrat prenevarna. Kljub temu se je promet na cesti Ljubljana-Zagreb leta 1992 zmanjšal na komaj 62,7\% tistega iz leta 1985, na cesti Maribor-Zagreb pri Podlehniku pa celo le na $61,4 \%$. Zaradi tolikšnega zmanjšanja prometa na dveh najprometnejših cestah se je zmanjšal tudi skupni PLDP za vseh 15 števnih mest, in sicer na $83,8 \%$, hkrati pa povečal na na prometno manj obremenjenih smereh. Največjo rast prometa kažejo prometnice na območju Metlike ( $v$ smeri proti jugu je bil indeks 170, v smeri proti vzhodu pa 213). Takšna rast prometa je nedvomno povezana tudi s pogostejšimi prehodi meje zaradi vojnih razmer v sosednji državi (begunci, oskrbovaje, delo itd.).

Leta 1992 je bil na smereh Ljubljana-Zagreb, Maribor-Zagreb in Postojna-Reka promet približno 4000 vozil dnevno (3554-4604). V smeri Novo mesto-Karlovac, Celje-Krapina in Lendava-Čakovec se je promet povečal na 1839-2794 motornih vozil leta 1992. Edina izjema je bila smer Trst-Reka, kjer se je promet zmanjšal. Na smereh z najmanjšim prometom: Kočevje-Reka, Črnomelj-Karlovac in Brežice-Klanjec se je promet le malenkostno povečal oziroma zmanjšal.

Največje spremembe je bilo opaziti v strukturi prometa pri razmerju med osebnimi in tovornimi vozili. Delež osebnih vozil za vse obravnavane ceste je bil leta $198579,6 \%$, leta 1992 pa kar 90,3\%. Ker je šlo za zmanjšanje obsega tovornega prometa na vseh števnih mestih lahko sklepamo, da je to posledica prekinitve tranzitnega tovornega prometa in zmanjšanja obsega blagovne menjave Slovenije z državami na območju bivše Jugoslavije. Najbolj se je zmanjšal delež tovornega prometa na cesti Koper-Buzet, in sicer od 18,7\% na samo $5,6 \%$. Zaradi upada tega prometa se je zmanjšal tudi skupni promet (indeks 95).

Zaradi vojnih razmer se tujci območju nekdanje Jugoslavije izogibajo, kar nam nazorno prikazuje manjši delež tujcev na slovensko-hrvaški meji. Delež tujih osebnih vozil je bil na 15. števnih mestih leta $198529,0 \%$, leta 1992 pa le $19,2 \%$. Do največjega zmanjšanja je prišlo na smeri Maribor-Zagreb. Od vseh vozil, ki so v povprečju dnevno peljala skozi Podlehnik, je bilo leta 1992 tujih vozil le $22,7 \%$, leta 1985 pa $53,0 \%$. Podobno se je delež tujih osebnih vozil zmanjšal tudi na cesti Trst-Reka, od $46,0 \%$ na $24,7 \%$. Enako velja tudi za smer Postojna-Reka, kjer je delež tujih osebnih vozil padel od 33,9\% na 17,3\%. Največji delež tujih osebnih vozil je bilo leta 1992 na cesti Koper-Pula, kjer so tuja osebna vozila predstavljala skoraj tretjino vseh vozil $(31,9 \%)$. Cesti Maribor-Zagreb in Trst-Reka sta kljub močnemu zmanjšanju prometa še vedno imeli višja deleža tujih osebnih vozil kot druge ceste $(22,7 \%$ in $24,7 \%)$ Še najbližja jima je bila cesta Koper-Buzet, na kateri se je delež tujih osebnih vozil celo precej povečal: od $14,2 \%$ na $19,2 \%$, a je bil celoten promet na tej cesti majhen (1492 motornih vozil leta 1992). Druge ceste s tako majhnim prometom so imele v glavnem zanemarljiv delež tujega osebnega prometa. Najmanjši delež tujih osebnih vozil $(0,8 \%)$ je bil v smeri od Metlike proti vzhodu. Ti deleži so bili na cestah s skromnejšim prometom majhni že leta 1985, vendar so se tudi na njih, z izjemo ceste Koper-Buzet, še izdatneje zmanjšali. Deleži osebnih vozil z območja nekdanje Jugoslavije so bili zelo visoki, višji od deleža slovenskih in drugih tujih osebnih vozil skupaj na cestah (Črnomelj-Karlovac, 
Novo mesto-Karlovac, Ptuj-Varaždin in Trst-Reka. Na drugih cestah število osebnih vozil iz nekdanje Jugoslavije leta 1992 ni presegalo števila domačih vozil.

\section{PROMETNI TOKOVI NA IZBRANIH MEJNIH PREHODIH}

Na podlagi ankete prometnih tokov, opravljene na izbranih mejnih prehodih. 31.7.1992 (MPZ, RUC, SCT, PNZ, 1992), lahko zapišemo naslednje temeljne ugotovitve.

Preko 22. mejnih prehodov v Sloveniji z Italijo (7 mejnih prehodov), Avstrijo (6 mejnih prehodov), Madžarsko (1 mejni prehod) in Hrvaško (8 mejnih prehodov) je 31.7.1992 prestopilo meje v obeh smereh 85.027 motornih vozil, med keterimi je bilo 79.819 osebnih $(94,0 \%), 4.286$ tovornih $(5,0 \%), 487$ motorjev $(0,6 \%)$ in 435 avtobusov $(0,5 \%)$.

Tab. 5: Število motornih vozil na mejnih prehodih Slovenije z Italijo, Avstrijo, Madžarsko in Hrvaško 31.7.1992 (prestop meje v obe smeri)*

Cross-Border Traffic by Road at the Slovene Borders with Italy, Austria, Hungary and Croatia 31.7.1992

\begin{tabular}{l|r|r|r|r|r}
\hline $\begin{array}{l}\text { Mejni prehodi } \\
\text { Border } \\
\text { crossings }\end{array}$ & $\begin{array}{r}\text { Motorna vozila } \\
\text { Motor } \\
\text { vehicles }\end{array}$ & $\begin{array}{r}\text { Motorji } \\
\text { Motor } \\
\text { cycles }\end{array}$ & $\begin{array}{r}\text { Osebna vozila } \\
\text { Private cars }\end{array}$ & $\begin{array}{r}\text { Avtobusi } \\
\text { Buses }\end{array}$ & $\begin{array}{r}\text { Tovornjaki } \\
\text { Lorries }\end{array}$ \\
\hline Italija & 32089 & 272 & 29840 & 160 & 1817 \\
Avstrija & 20399 & 120 & 19527 & 49 & 703 \\
Madžarska & 1098 & 3 & 919 & 12 & 164 \\
Hrvaška & 31441 & 92 & 29533 & 214 & 1602 \\
Skupaj & 85027 & 487 & 79819 & 435 & 4286 \\
\hline
\end{tabular}

*Analiza prometnih tokov čez mejne prehode v R Sloveniji, Ministrstvo za promet in zveze, Republiška uprava za ceste, SCT, PNZ, Prometni oddelek, Ljubljana, 1992

Na osmih mejnih prehodih s Hrvaško je leta 1992 prestopilo mejo 31.441 motornih vozil oziroma več kot tretjina $(37,0 \%)$ vseh motornih vozil čez slovenske meje, na sedmih mejnih prehodih z Italijo $32.089(38,0 \%)$ in na enem mejnem prehodu z Madžarsko $1.098(1,3 \%)$. Največ osebnih vozil je prestopilo slovensko-italijansko mejo (29.840), nekoliko manj slovensko hrvaško (29.533), sledili pa sta slovensko-avstrijska (19.527) in slovenskomadžarska meja (919). Na osmih mejnih prehodih s Hrvaško je mejo prestopilo v obe smeri 31.441 motornih vozil, od tega 29.533 osebnih vozil $(94,0 \%), 1.602$ tovornjakov $(5,1 \%)$, 214 avtobusov $(0,7 \%)$ in 92 motorjev $(0,3 \%)$. 
Tab. 6: Število motornih vozil na mejnih prehodih Slovenije in Hrvaške 31.7.1992 (prestop meje v obe smeri)*

Cross-Border Traffic by Road at the Slovene-Croat Border 31.7.1992

\begin{tabular}{l|r|r|r|r|r}
\hline $\begin{array}{l}\text { Mejni prehodi } \\
\text { Border } \\
\text { crossings }\end{array}$ & $\begin{array}{r}\text { Motorna vozila } \\
\text { Motor } \\
\text { vehicles }\end{array}$ & $\begin{array}{r}\text { Motorji } \\
\text { Motor } \\
\text { cycles }\end{array}$ & Private cars & $\begin{array}{r}\text { Avtobusi } \\
\text { Buses }\end{array}$ & $\begin{array}{r}\text { Tovornjaki } \\
\text { Lorries }\end{array}$ \\
\hline Središče ob D. & 1402 & 3 & 1141 & 12 & 246 \\
Gruškovje & 3444 & 1 & 3221 & 28 & 194 \\
Obrežje & 3645 & 2 & 3115 & 56 & 472 \\
Jelšane & 4359 & 12 & 4069 & 24 & 254 \\
Starod & 2225 & 0 & 2061 & 25 & 139 \\
Sočerga & 2344 & 19 & 2261 & 6 & 58 \\
Dragonja & 5683 & 28 & 5589 & 4 & 62 \\
Sečovlje & 8339 & 27 & 8076 & 59 & 177 \\
Skupaj & 31441 & 92 & 29533 & 214 & 1602 \\
\hline
\end{tabular}

*Analiza prometnih tokov čez mejne prehode v R Sloveniji, Ministrstvo za promet in zveze, Republiška uprava za ceste, SCT, PNZ, Prometni oddelek, Ljubljana, 1992

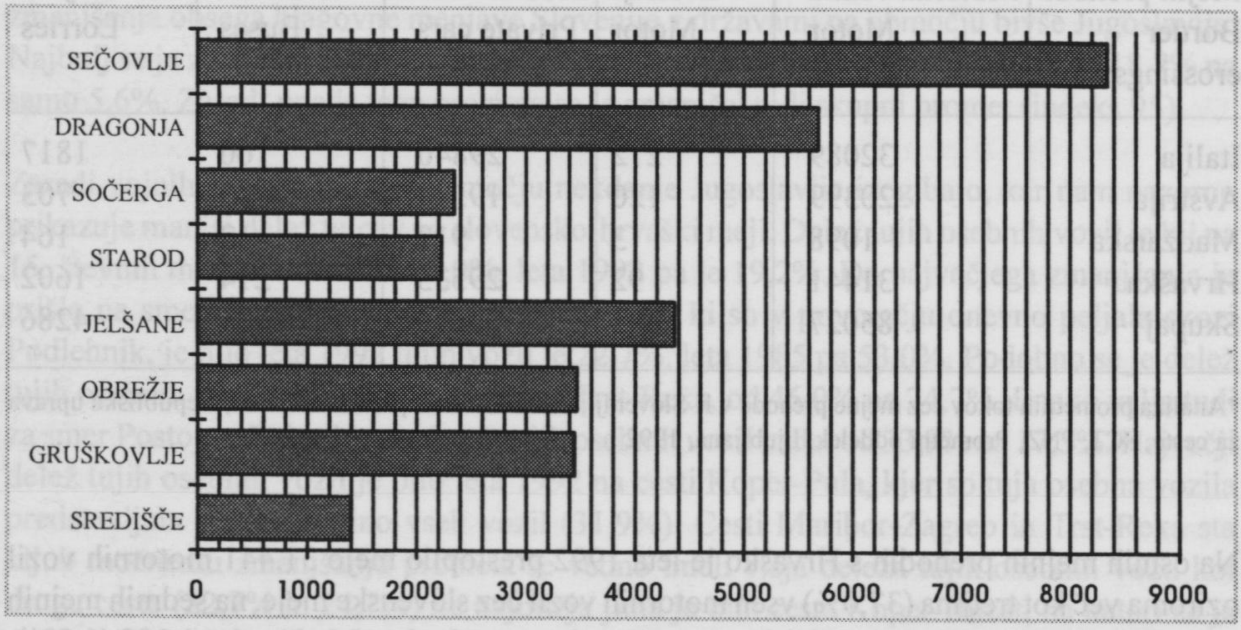

Slika 1: Število motornih vozil na slovensko-hrvaški meji (v obe smeri) 31. 7. 1992 Cross-Border traffic by road at the Slovene-Croat border 13.7.1992 (motor vehicles in both directions) 
Tab. 7: Število motornih vozil na slovensko-hrvaški meji (v obe smeri) 31.7.1992 Cross-Border Traffic by Road at the Slovene-Croat Border 13.7.1992 (motor vehicles in both directions)

\begin{tabular}{l|r|r|r|r}
\hline $\begin{array}{l}\text { Mejni prehodi } \\
\text { Border crossing }\end{array}$ & $\begin{array}{r}\text { Delo } \\
\text { Work }\end{array}$ & $\begin{array}{r}\text { Poslovno } \\
\text { Business }\end{array}$ & $\begin{array}{r}\text { Turizem } \\
\text { Leasure }\end{array}$ & $\begin{array}{r}\text { Drugo } \\
\text { Other }\end{array}$ \\
\hline Italija & 1641 & 3040 & 10078 & 15081 \\
Avstrija & 1753 & 2274 & 5689 & 9811 \\
Madžarska & 23 & 28 & 362 & 506 \\
Hrvaška & 1105 & 3550 & 15639 & 9239 \\
Skupaj & 4522 & 8892 & 31768 & 34637 \\
\hline
\end{tabular}

*Analiza prometnih tokov čez mejne prehode v R Sloveniji, Ministrstvo za promet in zveze, Republiška uprava za ceste, SCT, PNZ, Prometni oddclek, Ljubljana, 1992

Največ tovornih vozil je prečkalo slovensko-italijansko in slovensko-hrvaško mejo: preko prve 1.817 ali $42,45 \%$, preko druge pa 1.602 ali $37,4 \%$. Preko slovensko-avstrijske meje je prestopilo mejo le $16,4 \%$ vseh tovornih vozil, preko slovensko-madžarske pa 3,8\%. Največji delež tovornega prometa je po posameznih mejah imela slovensko-madžarska meja, kjer je bilo 1.098 vozil kar $15,0 \%$ tovornih. Na slovensko-italijanski meji je bil delež tovornega prometa $5,6 \%$, na slovensko-hrvaški meji $5,1 \%$ in na slovensko avstrijski meji le $3,4 \%$. Tudi ti podatki govore o prostorski usmeritvi blagovnih prometnih tokov preko slovenskega ozemlja.

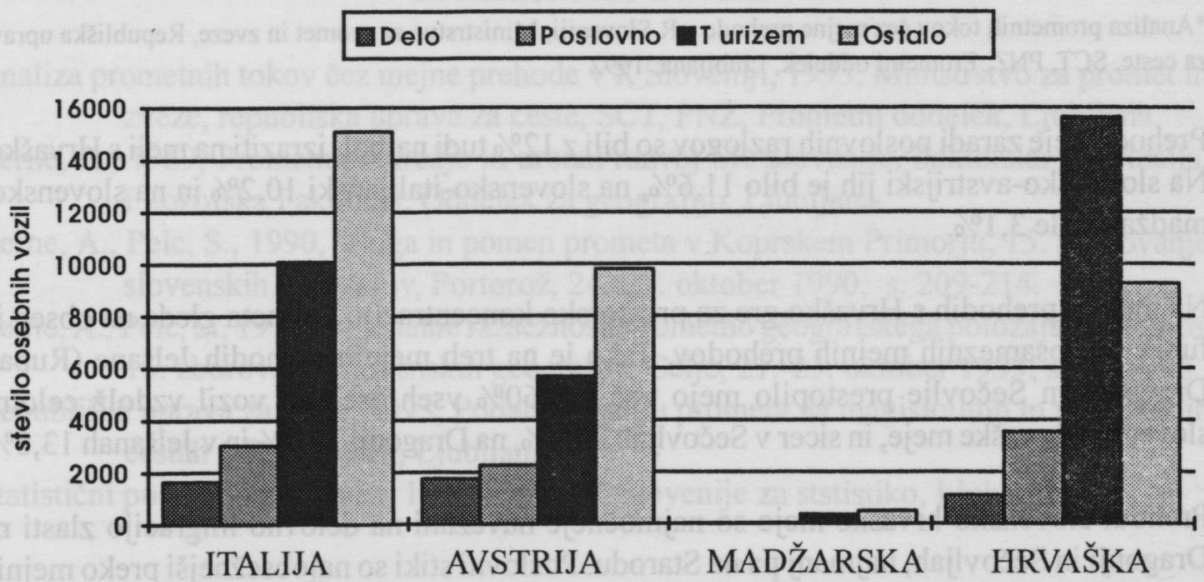

Slika 2: Prehod osebnih vozil na mejah Slovenije z Italijo, Avstrijo, Madžarsko in Hrvaško glede na namen 31.7.1992

Cross-Border Traffic of Private Cars According to the Purpose of Travel at the Slovene borders with Italy, Austria, Hungary and Croatia 31.7.1992 
Glede na namen potovanja osebnih vozil je prevladoval turizem, saj je skoraj $40 \%$ vseh osebnih vozil prestopilo mejo zaradi turističnih razlogov. Sledili so poslovni razlogi z $11,1 \%$, delovni s $5,7 \%$ ter ostali s $43,4 \%$. Na meji s Hrvaško so bili turistični motivi za prestop meje najštevilnejši, saj so predstavljali več kot polovico (53,0\%) prehodov vseh osebnih vozil. Na turizem je odpadlo na meji z Madžarsko 39,4\% osebnih vozil, na meji z Italijo $33,8 \%$ in na meji z Avstrijo $29,1 \%$. Ti podatki so smiselni, saj je bila anketa opravljena v času turistične sezone.

Tab. 8: Mejni prehodi osebnih vozil na slovensko-hrvaški meji glede na namen 31.7.1992* Cross-Border Traffic of Private Cars According to the Purpose of Travel at the Slovene-Croat Border 31.7.1992

\begin{tabular}{l|r|r|r|r}
\hline $\begin{array}{l}\text { Mejni prehodi } \\
\text { Border crossing }\end{array}$ & $\begin{array}{r}\text { Delo } \\
\text { Work }\end{array}$ & $\begin{array}{c}\text { Poslovno } \\
\text { Business }\end{array}$ & $\begin{array}{r}\text { Turizem } \\
\text { Leasure }\end{array}$ & $\begin{array}{r}\text { Drugo } \\
\text { Other }\end{array}$ \\
\hline Središče ob D. & 108 & 172 & 266 & 595 \\
Gruškovje & 58 & 624 & 601 & 1938 \\
Obrežje & 163 & 900 & 433 & 1619 \\
Jelšane & 74 & 294 & 2988 & 713 \\
Starod & 18 & 281 & 840 & 922 \\
Sočerga & 101 & 255 & 1529 & 376 \\
Dragonja & 284 & 349 & 3871 & 1085 \\
Sečovlje & 299 & 675 & 5111 & 1991 \\
Skupaj & 1105 & 3550 & 15639 & 9239 \\
\hline
\end{tabular}

*Analiza prometnih tokov čez mejne prehode v R Sloveniji, Ministrstvo za promet in zveze, Republiška uprava za ceste, SCT, PNZ, Prometni oddelek, Ljubljana, 1992

Prehodi meje zaradi poslovnih razlogov so bili z 12\% tudi najbolj izraziti na meji s Hrvaško. Na slovensko-avstrijski jih je bilo $11,6 \%$, na slovensko-italijanski $10,2 \%$ in na slovenskomadžarski le $3,1 \%$.

Na mejnih prehodih s Hrvaško gre za prostorsko koncentracijo prometa glede na obseg in funkcijo posameznih mejnih prehodov. Tako je na treh mejnih prehodih Jelšane (Rupa), Dragonja in Sečovlje prestopilo mejo več kot $60 \%$ vseh osebnih vozil vzdolž celotne slovensko-hrvaške meje, in sicer v Sečovljah $27,3 \%$, na Dragonji $19,0 \%$ in v Jelšanah $13,8 \%$.

Prehodi slovensko-hrvaške meje so najmočneje navezani na delovno migracijo zlasti na Dragonji in Sečovljah, najmanj pa na Starodu. Poslovni stiki so najobsežnejši preko mejnih prehodov Breg (1/4 vseh poslovnih prehodov osebnih vozil preko slovensko-hrvaške meje), Sečovlje (19,0\%) in Macelj (17,6\%). Najizrazitejši mejni prehodi za turistični promet pa so Seča, Dragonja in Jelšane. Na prvem je prestopilo mejo skoraj $1 / 3$ vseh osebnih vozil, ki so imela turistični namen potovanja, na Dragonji $1 / 4$ in v Jelšanah $19,1 \%$. 


\section{SKLEP}

Nova državna meja in krizno žarišče na Balkanu močno vplivata na zmanjšanje prometa na najbolj tranzitnih prometnih smereh v Sloveniji. Hkrati se je zaradi prekinitve medsebojnih trgovskih povezav močno zmanjšal tovorni promet med Slovenijo in Hrvaško. Zaradi bližine vojne se je zmanjšalo tudi število in delež tujih osebnih vozil. Na nekaterih delih meje, kjer poteka manjši promet, je prišlo do povečanja povprečnega letnega dnevnega prometa, kar je povezano $\mathrm{z}$ novonastalimi obmejnimi razmerami.

Tranzitni promet preko Slovenije se je preusmeril na longitudinalno smer Koper-Lendava, ki predstavlja infrastrukturno hrbtenico države. Hkrati je to tudi prometna smer, ki se ujema s predvidenim povečanjem prometa med razvijajočimi se državami vzhodnega dela srednje Evrope in industrijskimi območji sevrene Italije, južne Francije in Španije. Koncept nove prometne zasnove Slovenije bo zato temeljil prav na teh dejstvih in na zahtevi po neposrednem povezovanju z vsemi sosednjimi državami. Prometne smeri proti Hrvaški tako ne bodo imele več primarnega pomena kot v nekdanji državi, temveč sekundarnega, saj bosta imeli obe smeri Jesenice-Obrežje in Šentilj-Macelj pretežno tranzitni pomen. Leta pa verjetno ne bo imela prednosti pred medregionalnim in regionalnim povezovanjem $\mathrm{s}$ sosednjimi državami in regijami Slovenije. Prometni tokovi na obeh smereh se bodo $\mathrm{z}$ normalizacijo razmer ponovno krepili, čeprav verjetno ne bodo dosegli nekdanje ravni. Pričakovati je namreč, da bodo alternativne prometne smeri zaradi boljše infrastrukture v večji meri ustvarjale nove prometne potrebe.

\section{LITERATURA IN VIRI}

Analiza prometnih tokov čez mejne prehode v R Sloveniji, 1993, Ministrstvo za promet in zveze, republiška uprava za ceste, SCT, PNZ, Prometni oddelek, Ljubljana.

Černe, A., 1989, Prometno omrežje in urbani razvoj SR Slovenije, doktorska disertacija, Filozofska Fakulteta, Oddelek za geografijo, Ljubljana.

Černe, A., Pelc, S., 1990, Vloga in pomen prometa v Koprskem Primorju, 15. zborovanje slovenskih geografov, Portorož, 24.-27. oktober 1990, s. 209-214.

Černe, A., Pelc, S., 1993, regionalne razsežnosti prometno geografskega položaja Savinjske, 16. zborovanje slovenskih geografov, Celje, 21.-23. oktober 1993, s. 175-196.

Republiška uprava za ceste, 1993, Podatki o štetju prometa na magistralnih in regionalnih cestah v R Sloveniji, Ljubljana.

Statistični podatki po občinah, 1992, Zavod R Slovenije za ststistiko, Ljubljana. 


\section{TRANSPORT-GEOGRAPHIC ASPECTS OF THE NEW STATE BORDER}

\section{Summary}

Slovenia has $1,160 \mathrm{~km}$ of state borders, of which $546 \mathrm{~km} \mathrm{(47.0 \% )} \mathrm{is} \mathrm{shared} \mathrm{with} \mathrm{Croatia,}$ $324 \mathrm{~km}(28.0 \%)$ with Austria, $202 \mathrm{~km}(17.4 \%)$ with Italy and $88 \mathrm{~km}(7.5 \%)$ with Hungary. The Slovenian sea border is only $46.6 \mathrm{~km}$ long. There are altogether 149 border crossings on the Slovenian state borders: $65(43.6 \%)$ international and local roads, railroads, and other crossings with Italy, 48 (32.2\%) with Austria, 34 (22.8\%) with Croatia and 2 (1.3\%) with Hungary. At international border crossings, more than 18 million cars were registred in regular road traffic in 1990, with more than 90 million passengers.

On the basis of an average daily traffic flow per a year in 1985 and 1992 we can determine two main changes. Before the new state border we had three main traffic flows towards the border: Koper-Pula, Ljubljana-Zagreb and Maribor-Zagreb. Traffic flows in 1992 increased on the first direction and decreased on others two. This is specially evident in goods traffic and traffic of foreign private cars. On the other hand, trafic flows at regional and local border crossings increased because of daily commuters.

According to the analysis of cross-border traffic by road, 31.7.1992, 85,027 motor vehicles were registred in both directions at 22 border crossings at the Slovene borders. At the border crossings with Italy $32,089(37.7 \%)$ motor vehicles were registred, with Croatia $31,441(37.0 \%)$, with Austria 20,399 (24.0\%) and with Hungary 1,098 (1.3\%).

The structure of cross-border traffic at 8 border crossings at the Slovene-Croat border was as follows: 29,533 private cars $(94.0 \%), 1,602$ lorries $(5.1 \%), 214$ buses $(0.7 \%)$ and 29 motor cycles. The biggest traffic flow was at border crossings Sečovlje $(8,076$ private cars, or $27.3 \%$ of all registred private cars at Slovene-Croat border crossings), Dragonja $(5,589$ private cars, $19.0 \%)$ and Jelšane $(4,069$ private cars, $13.8 \%)$, leading towards the peninsula of Istra.

Turistic travel was the purpose of more than $50 \%$ of all private cars crossings at the SloveneCroat border, $12.0 \%$ were business travel, $3.7 \%$ were commuters and $31.3 \%$ were other purposes. 